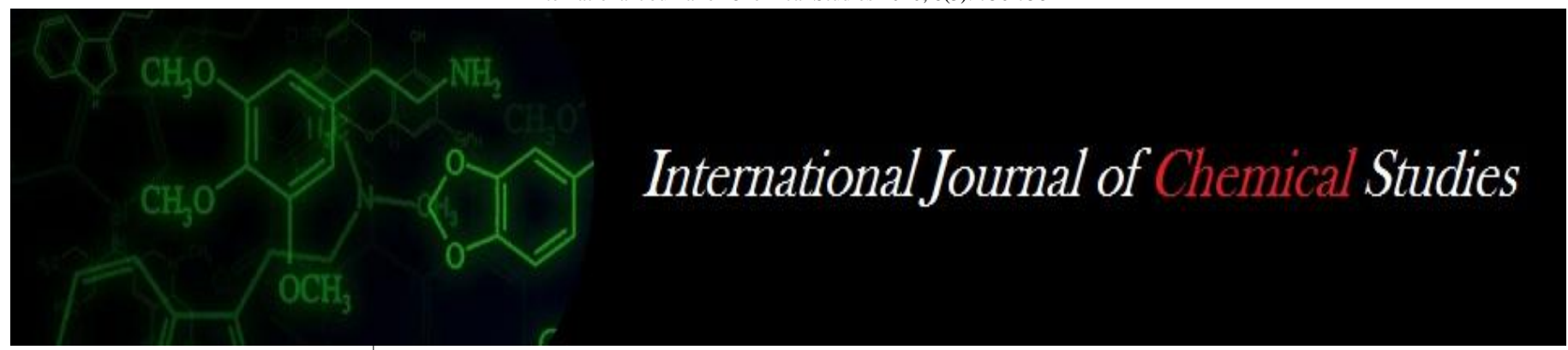

P-ISSN: 2349-8528

E-ISSN: 2321-4902

www.chemijournal.com

IJCS 2020; 8(3): 756-758

(C) 2020 IJCS

Received: 27-03-2020

Accepted: 30-04-2020

Varsha V Tapre

AICRP on Medicinal and Aromatic

Plants and Betelvine,

Nagarjun Medicinal Plants Garden, Vidyapeeth, Akola, Maharashtra, India

\section{SD Deshmukh}

AICRP on Medicinal and Aromatic Plants and Betelvine,

Nagarjun Medicinal Plants Garden Dr. Panjabrao Deshmukh Krishi Vidyapeeth, Akola, Maharashtra, India

\section{AG Deshmukh}

AICRP on Medicinal and Aromatic Plants and Betelvine, Dr. Panjabrao Deshmukh Krishi

Vidyapeeth, Akola, Maharashtra, India

\section{AR Pawar}

AICRP on Medicinal and Aromatic Plants and Betelvine,

Nagarjun Medicinal Plants Garden, Vidyapeeth, Akola, Maharashtra, India

\section{BM Muradi}

AICRP on Medicinal and Aromatic Plants and Betelvine,

Nagarjun Medicinal Plants Garden, Dr. Panjabrao Deshmukh Krishi Vidyapeeth, Akola, Maharashtra, India

\section{RB Sarode}

AICRP on Medicinal and Aromatic Plants and Betelvine,

Nagarjun Medicinal Plants Garden, Dr. Panjabrao Deshmukh Krishi Vidyapeeth, Akola, Maharashtra, India Dr. Panjabrao Deshmukh Krishi

Nagarjun Medicinal Plants Garden, Dr. Panjabrao Deshmukh Krishi

\section{Studies on floral biology and breeding behavior of Aloe (Aloe barbadensis)}

\author{
Varsha V Tapre, SD Deshmukh, AG Deshmukh, AR Pawar, BM Muradi \\ and RB Sarode
}

DOI: https://doi.org/10.22271/chemi.2020.v8.i3i.9296

\begin{abstract}
Aloe vera has anti-inflammatory, antioxidant, anti-microbial, anticancer, anti-diabetic, immune boosting and hypoglycemic properties. There are more than 75 active ingredients found in Aloe vera, including amino acids, vitamins, minerals, saponin aloesin, aloeemodin, methylchromones, flavonoids etc. from the inner gel of leaves. On behalf of ameliorations of such a divine medicinal plant, flower study is prerequisite for breeding programme. By considering the medicinal and economical importance of Aloe, the present study was therefore undertaken at Nagrjuna Medicinal Plants Garden, Dr. Panjabrao Deshmukh Krishi Vidyapeeth, Akola with a view to collect detailed information on floral biology breeding behavior of this divine plant. The flowers are bisexual, containing both male and female reproductive parts. The flowers had perianth of 6 petals with six stamens and ovary is superior, where the petals and stamens are inserted below the ovary. Maximum anthesis was observed from 09.00 to 10.00 am at $\mathrm{RH}$ of $61-66 \%$ and temperature ranged of $32.9-38.3{ }^{\circ} \mathrm{C}$. Anther dehiscence was maximum between 10.00 and $11.00 \mathrm{am}$. It is observed that the time between anthesis and anther dehiscence was nearly 1.00 $\mathrm{hr}$.
\end{abstract}

Keywords: floral biology, breeding, Aloe vera

\section{Introduction}

Aloe barbadensis $(2 \mathrm{n}=14)$ is an important medicinal plant of India belongs to the family Liliaceae (Tribe Aloineae) consisting of perennial tropical plants of African origin (Akinyele and Odiyi, 2007) and introduced to India (Chandra and Choudhari, 2014) ${ }^{[5]}$. The species occur in the Arabian Peninsula, through North Africa as well as Sudan and neighboring countries (Hossain et al., 2013) ${ }^{[7]}$. In India, it is commonly observed in Rajashthan, Andhra Padesh, Gujarat, Maharashtra and Tamil Nadu (Surjushe et al., 2008, Das and Chattopadhay, 2004) [14, 6]. The Aloe name derived from the Arabic word Alloeh or Hebrew "halal" means "shining bitter substances" (Ahlawat and Khatkar, 2011) ${ }^{[1]}$. Aloe vera is a stemless, perennial, drought resisting, succulent plant and has reportedly been used since ancient times for medicinal purposes (Klein and Penneys, 1988) ${ }^{[9]}$. Aloe vera is small, stem less, herbaceous and perennial plant with shallow root system. The fleshy, sword-shaped leaves are gray-green and grow to $80-90 \mathrm{~cm}$ long at the end of juicy green branches (Surjushe et al., 2008 and Akinyele, 2006) [14, ${ }^{2]}$. There is some preliminary evidence that Aloe vera extracts may be useful in the treatment of wound and burn healing, minor skin infections, sebaceous cyst, diabetes, and elevated blood lipids in humans (Boudreau and Beland, 2006) ${ }^{[4]}$. There are more than 75 active ingredients found in Aloe vera, including aloesin, aloeemodin, acemannan, aloeride, methylchromones, flavonoids, saponin, amino acids, vitamins, and minerals from the inner gel of leaves (Roy et al., 2012, Saeed et al., 2004, Patidar et al., 2012) ${ }^{[12,13,11]}$. It has anti-inflammatory, antioxidant, antimicrobial, anti-cancer, anti-diabetic (Patke et al., 2018) ${ }^{[10]}$, immune boosting and hypoglycemic properties which act as panacea for stroke, heart attacks, leukemia, anemia, hypertension, AIDS, radiation burns, digestive disorders (Hossain et al., 2013; Khyade and Shendage, 2012) ${ }^{[7,8]}$.

AICRP on Medicinal and Aromatic Plants and Betelvine,

Nagarjun Medicinal Plants Garden, Dr. Panjabrao Deshmukh Krishi Vidyapeeth, Akola, Maharashtra, India

\section{Methods and material}

The study of floral biology and breeding behavior of aloe been done at the Nagrjuna Medicinal Plants Garden, Dr. Panjabrao Deshmukh Krishi Vidyapeeth, Akola (MS). The ten mature plants were selected for study, racemes and flowers from these ten plants were selected to 
study floral biology and breeding behavior under field condition for 10 days. The flowers are bisexual, containing both male and female reproductive parts and also it is polycarpic i.e. it flowers and fruit sets many time in its life. Data were recorded under various morphological such as, length of racemes, no. of flowers per raceme, no. perianth, no. of stamens, length of perianth, androecium and style and flowering characters which are important for breeding viz., time and duration of anthesis and dehiscence in Aloe vera was estimated by using acetocarmine stain.

\section{Results}

Raceme development:

Inflorescences of Aloe vera were bright colored, cylindrical raceme \& tubular flowers grown from the center of the rosette of the leaves. It was observed that the development of flowers started from base to top of the raceme. The number of flowers in the raceme ranged from 57 to 116 . The length of fully developed raceme was ranged from 97 to $124 \mathrm{~cm}$. Profuse branching has not been observed so far. (Table 1)

The flowers are bisexual, containing both female and male parts. The flowers are perianth of 6 lobes, where sepals and petals are considered together. They have 6 stamens and the ovary is superior, where the sepals, petals and stamens are inserted beneath the ovary.

Table 1: Flower morphology of Aloe vera

\begin{tabular}{|c|c|c|c|}
\hline Traits & Dimension & Range & SD \pm \\
\hline Length of raceme & $109.75 \mathrm{~cm}$ & $(97-124)$ & 10.229 \\
\hline No. of flower per raceme & 94.3 & $(57-131)$ & 21.07 \\
\hline No. of Perianth & 6 & & \\
\hline No. of Stamens & 6 & & \\
\hline Shape of Ovary & Oval & & \\
\hline Length of Perianth & $3.34 \mathrm{~cm}$ & $(3.2-3.6)$ & 0.117 \\
\hline Length of Androecium & $3.44 \mathrm{~cm}$ & $(3.2-3.6)$ & 0.135 \\
\hline Length of Style & $2.59 \mathrm{~cm}$ & $(2.3-2.8)$ & 0.119 \\
\hline Weight of Flower & $0.622 \mathrm{~g}$ & $(0.55-0.72)$ & 0.058 \\
\hline
\end{tabular}

\section{Anthesis and dehiscence}

Anthesis and anther dehiscence of Aloe vera was observed at regular intervals of one hour from 6.00 am to $5.00 \mathrm{pm}$ for 10 days. Flowers were observed throughout the day to record the time of anthesis and anther dehiscence. Similarly time required by an individual inflorescence to bloom was also recorded.

\section{Anthesis}

The flowers were pendulous with orange color. The first opening of flower is called anthesis. The first sign of anthesis was indicated by appearance of longitudinal crack at the apex of corolla and it widens up to the middle of the bud and slowly one after another or simultaneously the petals of the bud separated and six stamens and stigma became visible. Maximum anthesis was observed from 08.00 to 09.00 am at $\mathrm{RH}$ of $62-67 \%$ and temperature ranged $27-30^{\circ} \mathrm{C}$. (Table 2 )

Table 2: Time and duration of anthesis in Aloe vera

\begin{tabular}{|c|c|c|c|c|c|c|c|c|c|c|c|c|c|}
\hline $\begin{array}{c}\text { Day of } \\
\text { observations }\end{array}$ & $\mathbf{6 . 0 0}$ A.M. & 7.00 A.M. & 8.00A.M. & 9.00 A.M. & 10.00 A.M. 11.00 A.M. 12.00 A.M. & 1.00 P.M. & 2.00 P.M. & 3.00 P.M. 4.00 P.M. 5.00 P.M. \\
\hline Day 1 & 0.00 & 6.45 & 19.35 & 3.23 & 0.00 & 9.68 & 6.45 & 12.90 & 3.23 & 6.45 & 12.90 & 19.35 \\
\hline Day 2 & 0.00 & 19.05 & 4.76 & 4.76 & 4.76 & 9.52 & 4.76 & 4.76 & 23.81 & 9.52 & 9.52 & 4.76 \\
\hline Day 3 & 0.00 & 15.38 & 19.23 & 26.92 & 3.85 & 3.85 & 7.69 & 0.00 & 7.69 & 11.54 & 0.00 & 3.85 \\
\hline Day 4 & 0.00 & 10.87 & 17.39 & 13.04 & 10.87 & 8.70 & 15.22 & 2.17 & 15.22 & 4.35 & 2.17 & 0.00 \\
\hline Day 5 & 3.03 & 21.21 & 24.24 & 9.09 & 0.00 & 12.12 & 9.09 & 3.03 & 3.03 & 3.03 & 6.06 & 6.06 \\
\hline Day 6 & 0.00 & 17.50 & 17.50 & 15.00 & 2.50 & 7.50 & 0.00 & 15.00 & 2.50 & 7.50 & 10.00 & 5.00 \\
\hline Day 7 & 0.00 & 11.11 & 14.81 & 16.67 & 11.11 & 9.26 & 7.41 & 7.41 & 5.56 & 7.41 & 3.70 & 5.56 \\
\hline Day 8 & 0.00 & 8.33 & 18.75 & 18.75 & 8.33 & 6.25 & 14.58 & 4.17 & 6.25 & 0.00 & 8.33 & 6.25 \\
\hline Day 9 & 0.00 & 14.58 & 18.75 & 20.83 & 10.42 & 6.25 & 10.42 & 0.00 & 8.33 & 4.17 & 4.17 & 2.08 \\
\hline Day 10 & 0.00 & 10.34 & 17.24 & 17.24 & 13.79 & 10.34 & 6.90 & 6.90 & 6.90 & 3.45 & 3.45 & 3.45 \\
\hline Mean & 0.30 & 13.48 & 17.20 & 14.55 & 6.56 & 8.35 & 8.25 & 5.63 & 8.25 & 5.74 & 6.03 & 5.64 \\
\hline Mean RH & 68 & 67 & 66 & 62 & 62 & 59 & 58 & 57 & 100 & 52 & 52 & 53 \\
\hline Mean Temp & 25.1 & 26.2 & 27.7 & 30.1 & 31.1 & 31.9 & 31.9 & 32.6 & 33.3 & 33.0 & 32.2 & 31.0 \\
\hline
\end{tabular}

\section{Dehiscence}

The bursting of pollen from anther i.e. dehiscence was maximum between 09.00 am to $10.00 \mathrm{am}$. Since the Relative humidity and temperature was $62 \%$ and $30-31^{\circ} \mathrm{C}$ at the time of peak pollen bursting. The bees and sunbird are responsible for pollination. The time between anthesis and Dehiscence was nearly $1.00 \mathrm{hr}$. (Table 3 )

Table 3: Time and duration of dehiscence in Aloe vera

\begin{tabular}{|c|c|c|c|c|c|c|c|c|c|c|c|c|}
\hline \multirow{2}{*}{$\begin{array}{c}\text { Day of } \\
\text { observations }\end{array}$} & \multicolumn{12}{|c|}{ Percentage of anther dehiscence in Aloe vera } \\
\hline & 6.00 A.M. & 7.00 A.M. & 8.00 A.M. & 9.00 A.M. & 10.00 A.M & 11.00 A.M. & 12.00 A.M & 1.00 P.M. & 2.00P.M. & 3.00 P.N & 00 P.M & .00 P.M. \\
\hline Day 1 & 0.00 & 0.00 & 0.00 & 9.09 & 31.82 & 0.00 & 13.64 & 4.55 & 9.09 & 13.64 & 4.55 & 13.64 \\
\hline Day 2 & 0.00 & 0.00 & 5.26 & 21.05 & 5.26 & 5.26 & 10.53 & 5.26 & 5.26 & 21.05 & 15.79 & 5.26 \\
\hline Day 3 & 0.00 & 0.00 & 20.00 & 16.00 & 16.00 & 12.00 & 8.00 & 8.00 & 0.00 & 8.00 & 12.00 & 0.00 \\
\hline Day 4 & 0.00 & 0.00 & 13.16 & 23.68 & 10.53 & 18.42 & 10.53 & 10.53 & 2.63 & 5.26 & 5.26 & 0.00 \\
\hline Day 5 & 0.00 & 0.00 & 24.14 & 17.24 & 6.90 & 0.00 & 10.34 & 10.34 & 13.79 & 6.90 & 3.45 & 6.90 \\
\hline Day 6 & 0.00 & 0.00 & 19.44 & 19.44 & 11.11 & 5.56 & 8.33 & 0.00 & 16.67 & 2.78 & 8.33 & 8.33 \\
\hline
\end{tabular}




\begin{tabular}{|c|c|c|c|c|c|c|c|c|c|c|c|c|}
\hline Day 7 & 0.00 & 0.00 & 11.76 & 15.69 & 17.65 & 11.76 & 9.80 & 7.84 & 7.84 & 5.88 & 7.84 & 3.92 \\
\hline Day 8 & 0.00 & 0.00 & 11.43 & 17.14 & 25.71 & 0.00 & 0.00 & 17.14 & 8.57 & 5.71 & 0.00 & 14.29 \\
\hline Day 9 & 0.00 & 0.00 & 18.75 & 14.58 & 20.83 & 10.42 & 6.25 & 10.42 & 0.00 & 10.42 & 4.17 & 4.17 \\
\hline Day 10 & 0.00 & 0.00 & 13.04 & 17.39 & 13.04 & 13.04 & 13.04 & 8.70 & 4.35 & 8.70 & 8.70 & 0.00 \\
\hline Mean & 0.00 & 0.00 & 13.70 & 17.13 & 15.89 & 7.65 & 9.05 & 8.28 & 6.82 & 8.83 & 7.01 & 5.65 \\
\hline Mean RH & 68 & 67 & 66 & 62 & 62 & 59 & 58 & 57 & 100 & 52 & 52 & 53 \\
\hline Mean Temp & 25.1 & 26.2 & 27.7 & 30.1 & 31.1 & 31.9 & 31.9 & 32.6 & 33.3 & 33.0 & 32.2 & 31.0 \\
\hline
\end{tabular}

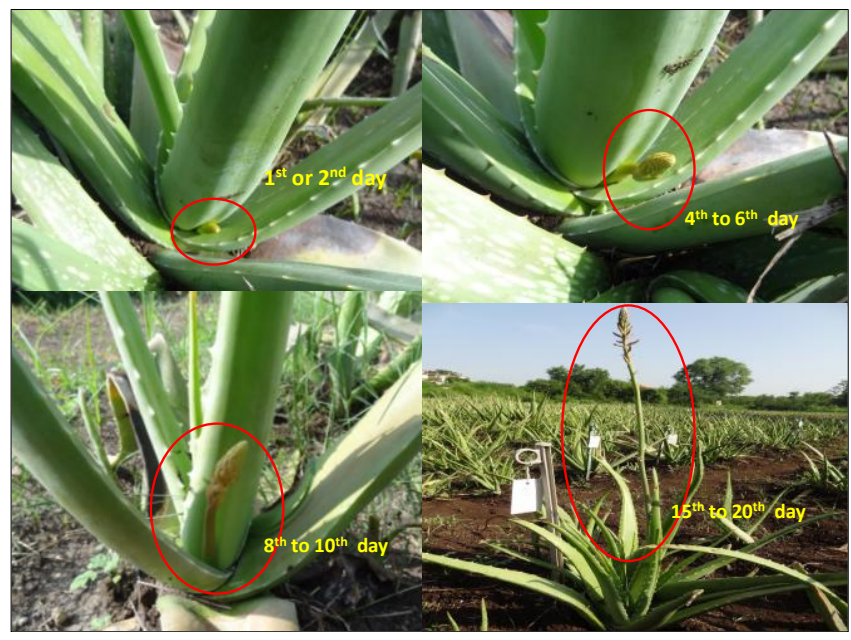

Development of Raceme in Aloe vera

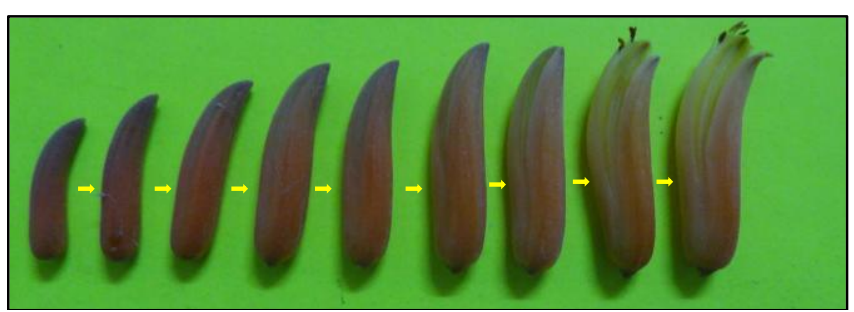

Stages of flower opening in Aloe vera

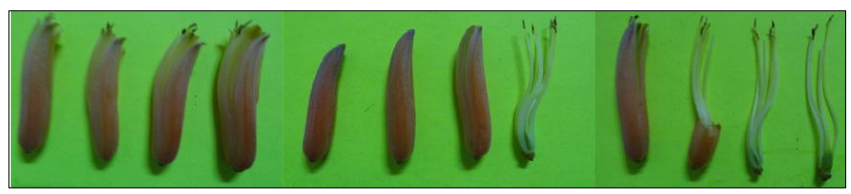

Dehiscence in Aloe vera

\section{Conclusion}

The flowers are bisexual, containing both male and female reproductive parts. The flowers had perianth of 6 petals with six stamens and ovary is superior, where the petals and stamens are inserted below the ovary. Maximum anthesis was observed from 09.00 to $10.00 \mathrm{am}$ at $\mathrm{RH}$ of $61-66 \%$ and temperature ranged of $32.9-38.3{ }^{\circ} \mathrm{C}$. Anther dehiscence was maximum between 10.00 and 11.00 am. The time between anthesis and anther dehiscence was nearly $1.00 \mathrm{hr}$.

\section{Reference}

1. Ahlawat KS, Khatkar BS. Processing, food applications and safety of Aloe vera products: A Review. J Food Sci. and Tech. 2011; 48(5):525-533.

2. Akinyele BO. Floral characters in the discrimination of the Nigerian Sp. of Aloe (Linn). Agril. J. 2006; 1(4):230234.

3. Akinyele BO, Odiyi. Comparative study of vegetative morphology and the existing taxonomic nutritional and medicinal status of Aloe vera L. African Crop Sci. Conference Proceedings. 2007; 8:1567-1570.
4. Boudreau MD, Beland FA. An evaluation of the biological and toxicological properties of Aloe barbadensis (Miller), Aloe vera. J. Environmental Sci. and Health. Part C, Environmental carcinogenesis and ecotoxicology reviews. 2006; 24(1):103-54.

5. Chandra D, Choudhary P. Diversity analysis of different accessions of Aloe Barbadensis Mill. (Syn. Aloe vera L.) collected from Rajasthan using RAPD marker system. The Bioscan. 2014; 9(1):7-10.

6. Das N, Chattopadhay RN. Commercial cultivation of Aloe. Natural product radiance. 2012; 3:85-87.

7. Hossain MS, Rashid ANM, Nayeem MT, Sen MK. A review on ethnopharmacological potential of Aloe vera L. J Intercult Ethnopharmacol. 2013; 2(2):113-120.

8. Khyade BV, Shendage NA. Influence of Aloe vera (1.) herbal formulation on the larval characters and economic paramateres of silkworm (Bombyx mori 1.) (Race: PM x CSR2). The Ecoscan: Special Issue. 2012; 1(32):1-326.

9. Klein AD, Penneys NS. "Aloe vera". J the American Academy of Dermatology. 1988; 18:714-720.

10. Patke NK, Varsha V, Tapre BM, Muradi SG, Wankhade, Sarode RB. Effect of Spacing and Organic Manures on Growth and Yield of Aloe Vera. Int. J Curr. Microbiol. App. Sci. Special Issue. 2018; 6:2492-2495.

11. Patidar A, Bhayadiya RK, Nimita M, Pathan JK, Dubey PK. Isolation of Aloin from Aloe vera, its characterization and evaluation for antioxidant activity. Int. J. of Pharmaceutical Res. and Development. 2012; 9:129-132.

12. Roy Upton, Pavel Axentiev MS, Diana Swisher MA. Aloe vera Leaf. American Herbal, 2012.Pharmacopoeia ${ }^{\circledR}$ 1-52. Available from: http://www.e-bookspdf.org

13. Saeed MA, Ahmad I, Yaqub U, Akbar S, Waheed A, Saleem M et al. Aloe Vera: A Plant of Vital Significance. Sci. vision. 2004; 9:1-13.

14. Surjushe A, Resham V, Saple DG. "Aloe vera: A short Review”. Indian J Dermatol. 2008; 53(4):163-6. 